\title{
Research on the Development Strategy of Eco-agricultural Tourism
}

\author{
Guo Gangzhi \\ Yiwu Industrial \& Commercial College, Yiwu, Zhejiang 322000
}

Keywords: eco-agriculture; tourism; strategy; environment; consumption; brand

\begin{abstract}
With the improvement of people's material living standards, the increasing pressure of urban work and the deteriorating urban environment, eco-agriculture tourism has the potential and space for development. However, for now, there are many problems that need to be further improved for the current development of eco-agriculture tourism. Based on the current small scale of eco-agriculture tourism and fewer customers, this research proposes a targeted, feasible and effective development strategy, which provide reference for the development of eco-agriculture tourism.
\end{abstract}

\section{Introduction}

In the 21st century, along with the deterioration of the global environment and the improvement of people's material living standards, tourism has developed rapidly and has spawned many new tourism development models. Eco-agricultural tourism is one of them. The integration of ecoagriculture and tourism can not only promote rural economic development, increase farmers' income, but also promote rural infrastructure construction, optimize rural industrial structure, and meet the daily sightseeing and entertainment needs of urban residents. Therefore, eco-agriculture tourism has developed rapidly in recent years and has been supported by policies [1]. Due to the short history of eco-agriculture tourism and the integration of multiple industries, there are still many problems that require strategic adjustment and optimization.

\section{Problems in the Development of Eco-agriculture}

At present, the overall development of eco-agriculture tourism is small, mainly in the suburbs of nearby cities, historic towns and villages. However, most tourists come because of famous attractions, rather than going straight to eco-agricultural tourist attractions. From this point, ecoagricultural tourism still needs to be improved and promoted.

Now, eco-agricultural tourism is mainly based on the tourist groups of neighboring cities and cannot be extended to the whole country. Generally, it can be completed in less than one day. However, most tourists choose to go on Saturdays and Sundays. They are more willing to travel to places that are moderately located in their own area. The shorter eco-agricultural tourist areas are generally not their primary choice. Therefore, the corresponding source of tourists is also not much [2].

Due to various factors, such as unreasonable policies for the farmers' benefits, lack of funds, backward concepts, uncoordinated living habits, low level of catering, incomplete entertainment facilities, poor accommodation, etc., it is difficult to stimulate consumption, the overall economic benefit of eco-agricultural tourism is low, and the development stamina is obviously insufficient..

In order to attract more tourists, eco-agricultural tourism projects must mold a brand. An effective way is to echo the characteristic culture of the region, coordinate development, and produce special products. However, the current development of the theme cultural tourism products of eco-agricultural tourism projects is not obvious, lacks creativity and cultural connotation, does not have the brand of local historical and cultural resources, and the material intake and refinement of natural landscapes are not deep enough to form a brand effect.

Right now, there are only a handful of highly educated people who are engaged in ecoagriculture tourism. This is partly because the eco-agricultural tourism industry is not attractive 
enough for highly educated professionals, and the main practitioners in eco-agricultural tourism are farmers. Although they have always had the reputation of being honest and hospitable, but due to lack of professional knowledge and quality training, driven by economic interests, they may snatch the source of tourists, pulling customers, forcibly selling products and even raising the price of goods without authorization.

\section{Development Strategy of Eco-agriculture Tourism}

Rational selection of eco-agricultural tourism development model is the basic prerequisite of sustainable development of eco-agriculture tourism, combined with the characteristics and advantages of eco-agricultural tourism resources, there are several models at present, which can be selected according to the actual situation.

Eco-agricultural park model. The development of this model focuses on the hilly area, in the hilly area, combined with the unique natural vegetation of the area, as well as the construction of artificial forests and economic forests, and the development of multi-functional leisure and tourist attractions. Develop deep forest sightseeing, build artificial forest farms, virgin forests, green parks and other facilities, and provide visitors with scientific research, leisure and entertainment, sightseeing, camping training, forest exploration, and summer vacation. At the same time, the development of recreational projects with garden features, such as bungee jumping, camping and other projects to attract customers, making it a unique ecological agricultural tourism destination.

The theme agricultural park model. This mode is a resort-type tourist attraction mainly for leisure and sightseeing. The development location is suitable for towns and suburbs near the city. The main projects are local ecological farmland, horticultural training hall, flower planting base, and special vegetable breeding base. According to the different planting characteristics of each region, the theme is set up. For example, according to the different crops, the theme park will be built for visitors to learn and enjoy, so that different themes will bring different experiences to visitors.

Participation, shopping, and experiential agricultural park models. This is a development model that is not limited by the natural environment and can be used as a supplement to the above model. This model focuses on stimulating tourists' consumption and increasing the sensory experience of tourists while promoting eco-agricultural products. For example, fishing, agricultural picking, free green fruit and vegetable tasting, and special agricultural souvenir shopping centers. Based on all available agricultural resources, visitors will enjoy it, and at the same time increase the income from tourism by purchasing agricultural and sideline products or souvenirs.

High-tech agricultural park model. The high-tech agricultural park is mainly for the display and visit of new agricultural technologies. For example, it can develop wine high-tech agronomic parks with high ornamental value, or use modern viticulture methods to develop modern planting with leisure sightseeing functions. As a platform that can simultaneously display new agricultural technologies, visitors will have the opportunity to visit closely for crop cultivation and breeding areas, solar greenhouse cultivation test demonstration areas, flower seedlings special fruit test demonstration areas, special livestock and poultry breeding areas and sightseeing and entertainment areas. On the one hand, it shows new types of agricultural technology, on the other hand, it improves economic efficiency.

Compound agricultural park model. A single tourism project cannot meet the differential tourism needs of tourists, which requires a combination of multiple tourism modes, namely the development of a composite agricultural park. This model develops a variety of tourism facilities while improving the quality of the tourist area to meet the different needs of different tourists.

Eco-agricultural tourism must take the road of molding distinctive brands instead of imitating and learning. It is necessary to start from the advantages of resources, highlight own characteristics, and build distinctive brands, which is the key to maintaining the long-lasting vitality of ecoagricultural tourism products.

Cultivation of special tourism products. For eco-agriculture tourism, to maintain long-term vitality and competitiveness, it is necessary to constantly introduce new products, create unique 
tourism products, and attract tourists with novel and distinctive tourism projects. With the increasing diversification of tourism demand by contemporary tourists, if they want to sell their tourism products and attract customers in the source market, they must tap the product characteristics and shape the brand to meet the changing needs of different tourists. It can start from the following: First, enrich tourism products, make the scenic spot have more tourism projects, integrate various elements of agriculture, forestry, animal husbandry and fishery, form a diverse product portfolio, attract tourists and extend customers staying time, promoting consumption; second, enhancing the participation of tourism products, making participatory one of the tourism characteristics, allowing visitors to experience activities such as farming, horse-raising, picking fruits and vegetables; third, improve the scientific and technological content of eco-agricultural tourism, let tourists understand the new technologies of eco-agriculture and the cultivation of organic vegetables, ecological farming, allowing visitors to face the production of local agricultural products, and thus promote the purchase demand.

The molding of special tourism brands. Overall planning the infrastructure of the scenic spot, and paying attention to the planning and construction of characteristic building facilities, focusing on creating characteristic agricultural scenic spots and local cultural display centers. As far as possible, it reflects humanistic care and affinity for tourists, strives to achieve "One step, one landscape; step by step, always landscape", breaks the traditional way of attracting tourists by individual attractions. Do a good job in planning, organizing and packaging of tourism products, and creating a distinctive eco-agricultural tourism project brand.

The development of eco-agriculture tourism is lacking in policy due to the backward development of rural economy. It is still at primary stage and requires the government to regulate management.

The government plays a leading role. On the one hand, it provide policy support, on the other hand, it manages the overall situation and create an excellent development environment for regional eco-agriculture tourism. Three main points should be achieved: First, the county, city, or township that carries out eco-agricultural tourism will release agricultural loan interest reduction and agricultural tax reduction and exemption policies; second, introduce relevant policies to manage and encourage the development of eco-agriculture tourism; third, priority allocation for the reconstruction of scenic spots Facility construction.

Making related policies. It is necessary to clarify the relevant policy system, conduct mandatory management of the services of the scenic spots according to the assessment indicators, and provide guidance to require the infrastructure facilities such as sanitation facilities and safety facilities of the scenic spots to meet the standards. In addition, the establishment of non-governmental organizations, such as the Eco-Agriculture Tourism Association and the Tourism Foundation, will enable mutual exchange and mutual supervision of scenic spots, and enhance the market influence and attractiveness.

Make a transportation development plan for the tourism industry. To develop tourism, to design first. Designing well is a prerequisite for the development of eco-agriculture tourism, and road design is the cornerstone. Therefore, it is necessary to formulate a reasonable transportation development design, to achieve overall management, layered responsibility, and coordinated development in design, fully integrate the characteristics of local eco-agriculture tourism, including market characteristics, geographical location characteristics, etc., and use all advantages to improve transportation services level, give play to investment benefits and meet the needs of ecological agriculture tourism development.

Reasonably plan transportation and tourism roads. The layout of transportation and tourism roads should not only enable tourists to enjoy beautiful scenery along the way, but also have the basic characteristics of quickness and convenience. On the basis of not affecting the farmland cultivation, the route should be placed in the vicinity of the farmland, so that visitors can experience "green, natural and ecological" eco-agricultural tourism during the journey and improve the satisfaction of tourists. 


\section{Conclusion}

Eco-agricultural tourism is an important part of tourism and has great development prospects. Due to the short development of this tourism model, there are still many problems. It is necessary for the government, enterprises and farmers to cooperate to improve the development of ecoagriculture tourism. The article puts forward the development strategy of eco-agriculture tourism, which provides certain practical reference.

\section{References}

[1] XiecYuping. On the progress of the research on eco-agricultural tourism in China [J]. Journal of Shaoyang University (Natural Science Edition), 2007, (2):105-109.

[2] Qiao Jie, Le Teng. The present situation and countermeasure of analysis about the development of eco-agriculture tourism in Hebei province [J]. Ecological economy, 2016, 32(2):133-138. 